\title{
NO EFFECTS OF WATERPROOF MARKING ON THE BEHAVIOUR AND GROWTH OF PHYSA ACUTA DRAPARNAUD, 1805 (GASTROPODA: HYGROPHILA: PHYSIDAE) IN THE LABORATORY
}

\author{
PAOLA LOMBARDO ${ }^{*}$, FRANCESCO PAOLO MiCCOLI ${ }^{2}$, ANNA CiCHY ${ }^{3}$, ANNA STANICKA ${ }^{3}$, \\ ELŻBIETA ŻBIKOWSKA ${ }^{3}$
}

\begin{abstract}
${ }^{1}$ Limno Consulting, via Bedollo 303, I-00124 Rome, Italy (e-mail: p.lombardo@limnoconsulting.com); (1) https://orcid.org/0000-0003-0058-7692

${ }^{2}$ Department of Medicine and Life Sciences (MESVA), Coppito Science Centre, University of L'Aquila, I-67100 Coppito (L'Aquila), Italy; (i) https://orcid.org/0000-0001-6748-6437

${ }^{3}$ Faculty of Biological and Veterinary Sciences, Department of Invertebrate Zoology and Parasitology,

Nicolaus Copernicus University in Toruń, Lwowska 1, 87-100 Toruń, Poland;

(1) AC https://orcid.org/0000-0001-7827-0738; () AS https://orcid.org/0000-0002-4287-8482;

(1) EŻ https://orcid.org/0000-0002-6126-8540

*corresponding author
\end{abstract}

\begin{abstract}
Physa acuta Draparnaud, 1805 is one of the most common freshwater gastropod species, with worldwide distribution. It is an effective periphyton grazer and a potential keystone species in shallow-water systems, where it can boost macrophyte well-being and thus help maintain high water clarity even in nutrientrich habitats. $P$. acuta also has been extensively studied in ecotoxicological and behavioural investigations. Such investigations may require observations on individual snails. A method to distinguish individual snails in small-scale experiments is marking their shells with paint dots. However, such marking must not influence snail behaviour (nutritional, reproductive, respiratory, etc.) or growth to avoid confounding effects. Earlier investigations point to no or very limited effects of marking on aquatic and terrestrial snail survival, behaviour, and growth. We tested whether marking could affect the behaviour (as snail activity) and growth of $P$. acuta using a waterproof, oil-based, non-toxic, fine-point car-body paint marker. Snails were divided into a "marked" and an "unmarked" (control) group of ten snails each in an eight-day experiment. The marking had no effect on the snail activity or growth. The snails survived the experiment and produced egg clutches well beyond the eight-day period. The marking persisted without fading during and beyond the experimental period. Our results support earlier findings that the use of oil-based, non-toxic markers can assist in carrying out reliable observations on individual snails, including the small-bodied P. acuta. Combinations of two dots of different colours allow simultaneous observations on a high number of replicate individuals.
\end{abstract}

KEY WORDS: freshwater gastropods; snail growth; snail behaviour; methodology

\section{INTRODUCTION}

Freshwater gastropods are among the most intensively studied aquatic organisms. Gastropods may play a keystone role in benthic littoral food webs as heavy periphyton and plant litter grazers (CATTANEO \& KALFF 1986, LOWE \& HUNTER 1988, GROSS \& LOMBARDO 2018), thus maximising access to light and nutrients for the photosynthetic organs of submerged macrophytes (e.g., JONES et al. 2000, TÓTH 2013). Healthy macrophytes in turn maintain or enhance water transparency even in nutrient-rich waters by many concurrent mechanisms, including allelopathic and/or competitive action against phytoplank- 
ton (e.g., JASSER 1995, KÖRNER \& NICKLISCH 2002, LOMBARDO et al. 2013), limitation of re-suspension of nutrient-rich sediments (VERMAAT et al. 2000), shading (FRODGE et al. 1990, DOYLE \& SMART 1998), and providing a daytime refuge against fish predation for zooplankton (BURKS et al. 2002, PĘCZUŁA et al. 2017). Grazing on living macrophyte tissue is rare (SOSZKA 1975, NEWMAN 1991, GROSS \& LOMBARDO 2018) and seems limited to relatively large snail species such as Lymnaea stagnalis (Linnaeus, 1758) on soft-leaved macrophyte species (PIECZYŃSKA 2003, ELGER \& LEMOINE 2005, ZHANG et al. 2020).

The relatively small-bodied physids (Hygrophila) Physa acuta Draparnaud 1805 [= P. integra (Haldeman, $1841)=$ P. heterostropha $($ Say, 1817) $=$ Physella acu$t a=$ Haitia acuta $]$ and $P$. fontinalis (Linnaeus, 1758) are particularly effective as periphyton grazers and macrophyte enhancers (e.g., MCCOLLum et al. 1998, JONES et al. 1999, LOMBARDO 2001). The common occurrence of $P$. acuta, its potential keystone role as a grazer in shallow-water habitats, and ease of laboratory rearing have also led to its use as a model aquatic organism in many studies (e.g., SPYRA et al. 2019, TARIEL et al. 2020).

Such research may require following individual snail growth and/or behaviour in space and/or time. In such cases, a need to distinguish the individual experimental snails may arise. Although marking individual animals for observational/experimental purposes is a common practice (HEIDINGER et al. 2009 and references therein), it has seldom been used for

\section{MATERIAL AND METHODS}

\section{EXPERIMENTAL ORGANISM}

The taxonomy of the genus Physa Draparnaud, 1801 (= Physella Haldeman, 1842 = Costatella Dall, 1850 = Haitia Clench et Aguayo, 1932) has recently been revised following detailed research in molecular biology, body anatomy, and reproductive behaviour. Such recent findings point to a grouping of several Physa species into a single species. DILLON et al. (2002) and WeTHINGTON \& LYDEARD (2007) proposed to assign it the oldest name, P. acuta. We follow such nomenclature.

Although considered a native European species for decades, P. acuta is a North American native, possibly accidentally brought to western Europe during the cotton trade in the mid 1700s (ANDERSON 2003, LYDEARD et al. 2016, VINARSKI 2017). P. acuta spread rapidly eastwards and into Mediterranean Europe (LYDEARD et al. 2016, VINARSKI 2017), where it quickly displaced and often replaced the native $P$. fontinalis (CIANFANElli et al. 2007). P. acuta is found in all 20 administrative regions in Italy in all types of inland gastropods (HENRY \& JARNE 2007). The few studies that used individual markings on terrestrial or aquatic gastropods did not show any negative marking effects on snails (FENWICK \& AMIN 1983, O'KeEFFE 1985, BAKER 1988, BURRIS et al. 1990, GOSSELIN 1993, MCRAE \& LEPITZKI 1994, BAMINGER 2000, HENRY \& JARNE 2007, TARIEL et al. 2020). The most common ways to mark individual snails were plastic tags attached with some kind of glue, nail varnish, enamel, or waterproof car-body paint (review in HENRY \& JARNE 2007). The waterproof car-body paint was suggested as the best possible marking method for short- and medium-term observations (HENRY \& JARNE 2007), while other paints, such as corrective white-out for paper and gouache paint, dissolve or chip quite quickly (HENRY \& JARNE 2007). We therefore further tested if one possible method to distinguish individual snails, namely marking their shells with a waterproof car-body paint, was a feasible approach for short- and medium-term field and laboratory experiments using the small-bodied, common freshwater gastropod P. acuta (Hygrophila: Physidae).

We organised individual $P$. acuta into two groups, a "marked" treatment and an "unmarked" control, in an eight-day experiment in small containers $(200 \mathrm{~mL})$, to ascertain whether the officially non-toxic, oil-based, waterproof fine-point CE- and RoHS-compliant marker used on snail shells could affect snail growth and behaviour. Our experiment had the additional aim to test if the marking was as waterproof as the manufacturer claimed.

waters (CIANFANELLI et al. 2007). It is regarded as invasive in south-western and Mediterranean Europe, while its colonisation of new habitats in colderclimate areas is often non-invasive (e.g., MicHALIKKUCHARZ 2008, LYDEARD et al. 2016, SPYRA et al. 2019). P. acuta's successful colonisation of new areas has led this species to become one of the most cosmopolitan aquatic invertebrates (DILlON et al. 2002).

Snails used in this experiment were taken from a parasite- and predator-free long-term culture started from individuals collected at the pond of Cascina Bellezza $\left(44^{\circ} 54.72^{\prime} \mathrm{N}, 07^{\circ} 47.27^{\prime} \mathrm{E}\right)$ in the Stagni di Poirino-Fàvari (Poirino-Fàvari Ponds) "Nature 2000" Site of European Importance (SIC IT 1110035) located $\sim 30 \mathrm{~km}$ south of the city of Turin, Italy (EVANGELISTA \& VAllinOtTO 2009). P. acuta is common at the Cascina Bellezza pond (Mr. M. EvANGELISTA, pers. comm.; P. LOMBARDO, pers. observ.).

The parental and culturing aquaria were kept in the outdoor laboratory of Limno Consulting in suburban Rome, Italy $\left(41^{\circ} 43.88^{\prime} \mathrm{N}, 12^{\circ} 21.42^{\prime} \mathrm{E}\right)$, where the field-collected parental snails appeared to have 
adapted at once upon arrival. The parental and culturing aquaria were placed in an area protected from strong winds, direct sunlight, and extreme temperatures. European P. acuta is at low risk of parasitic infection (TOLEDO et al. 1998, GÉRARD 2001). However, the parental $P$. acuta that gave origin to the culturing population were kept separate from their offspring, with egg clutches removed from the parental aquarium and left to hatch in the culturing aquarium. Such a method produced a parasite-free culturing aquarium, even though the parental snails were not checked for parasites.

\section{EXPERIMENTAL DESIGN AND SETUP}

The experiment was carried out alongside the culturing aquaria in the outdoor laboratory of Limno
Consulting in suburban Rome, central Italy. Twenty sub- and young adults of $P$. acuta were collected randomly (except for general body size) from the parasite- and predator-free post-parental culture. The snails were placed on absorbent paper and their body size was measured as shell height with an electronic DIN862-compliant Metrica (San Donato Milanese, Italy) 10008 precision calliper (accuracy $\pm 0.03 \mathrm{~mm}$ ). The ranges of shell height at the beginning of the experiment were $5.0-7.5 \mathrm{~mm}$ and $5.4-7.9 \mathrm{~mm}$ for marked and unmarked snails, respectively. Although the exact age of our experimental snails could not be determined as parental snails oviposited continuously and hatchling size at birth was too small to be measured with our calliper, such shell sizes are typical of sub-adults or adults at the initial stages of reproductive age (e.g., PERRIN 1986). Snails were left
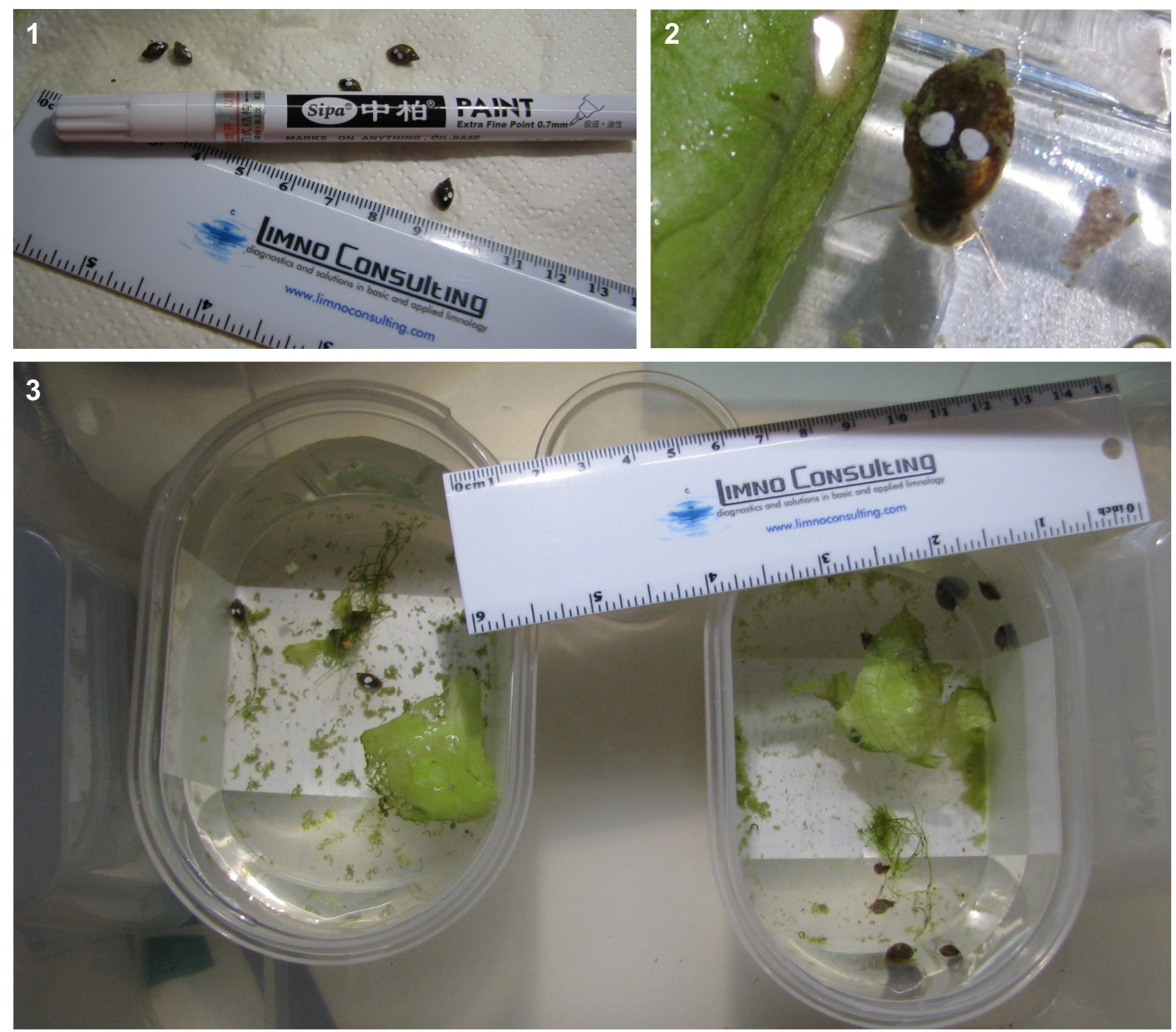

Figs 1-3. Outline of materials and methods: 1 - snails were marked with a fine-point white marker after having been partially dried on absorbent paper; 2 - a marked P. acuta in its experimental container with a lettuce leaf; 3 - the two containers, each containing ten experimental snails, as seen from above 
for $\sim 5$ min on the absorbent paper until the shell appeared dry (Figs 1-3). A white oil-based, non-toxic, waterproof fine-point "Sipa SP150" marker (Sino Path Enterprises Ltd, Hong Kong, China: http:// www.sipa.com.hk/) advertised for use as car-body paint was used to paint two $\sim 2-\mathrm{mm}$ dots on the dorsal shell area of ten snails (Fig. 2). The snails were then left on the absorbent paper for another $\sim 2-3$ min to allow the white dots to dry, and then placed in one of two small clear-plastic containers along with $\sim 200 \mathrm{~mL}$ of clean tap water (the same water used for the long-term culturing aquarium) (Figs 1-3). The snails left unmarked underwent the same pretrial handling except for the marking. The two small containers: treatment - "marked" and control - "unmarked" were then placed on a shelf in a well-lit area (Figs 1-3) alongside the culturing aquaria. Snails were fed ad libitum before and during the experiment with fresh "baby leaf" and trocadero lettuce, both tender-leaf variants of head lettuce (Lactuca sativa var. capitata), supplemented every four days with a few flakes of commercially available protein-rich food for ornamental fish.

The experiment lasted eight days during 1-9 March 2020 (light/dark cycle 11:27/12:33). Low (night time) air temperature (determined with a BAR208HGA Oregon Scientific weather station) was $9.7 \pm 2.7{ }^{\circ} \mathrm{C}$ and high (daytime) temperature was $15.9 \pm 1.3{ }^{\circ} \mathrm{C}$ (mean \pm standard deviation; $\mathrm{n}=8$ for both). Water $\mathrm{pH}$ (measured with an Oakton pHTestr 30) remained in the $8.2 \pm 0.5$ range.

The snails were observed twice a day, once in daytime at about 14:00 $\mathrm{h}$ [i.e., the time of activity peak according to LOMBARDO et al. (2010)], and once at night time in the 0:00-2:00 period. The degree of activity of individual snails was recorded following LOMBARDO et al.'s (2010) scheme with a slight modification (Table 1). LOMBARDO et al. (2010) found that observations at three-hour intervals did not influence the snail behaviour in the next observation, so our 12-hour interval between the observations can be also safely considered as producing independently collected data. As in LOMBARDO et al. (2010), night time observations were carried out with a red-light flashlight which does not disturb the animals (e.g., PECKARSKY \& COWAN 1995).

The water in the experimental containers was refreshed at the end of the first cycle of four days as it had become foul, thus possibly influencing the snail behaviour (e.g., CHAUDRY \& MORGAN 1987). All the snails appeared in good health and several egg clutches were produced in both containers at the end of the first and the second four-day period.

The snails were retrieved from the experimental containers after a total of eight daytime and eight night time consecutive observations. All the snails survived the experiment and kept ovipositing for at least another six weeks after the end of the experimental period. Growth was determined as changes in shell height, with final shell height measured as for initial height. Shell height is a reliable proxy to estimate snail growth (e.g., RID 2008).

\section{NUMERICAL AND STATISTICAL ANALYSIS}

The observed activity was expressed numerically following the qualitative-to-quantitative conversion in Table 1. The individual activity was summed across the 10 replicate snails to allow the statistical analysis to be carried out with ANOVAs and t-tests, which are much more robust and reliable than $\chi^{2}$ based contingency tables (e.g., ZAR 2009). Normality tests were not carried out because of the robustness of the ANOVA and t-test with mild non-normality and heteroskedasticity (ZAR 2009); the analysis robustness was further maximised by the balanced experimental design (UNDERWOOD 1997, ZAR 2009). The group activity summed across the ten replicate snails could range from zero (if all ten snails were found dead) through 40 (if all ten snails were observed in "high activity" mode). The "group activity" approach also further maximised the analysis robust-

Table 1. Four categories of pulmonate snail activity, listed from least active (top) to most active (bottom). Snails were considered inactive when observed as either inact- or inact + , and active when observed as either act- or act + . The 0-4 scale used in our experiment is slightly modified from LOMBARDO et al. (2010), who did not include mating as they observed the snails as physically separate individuals.

\begin{tabular}{clr}
\hline & \multicolumn{1}{c}{ Activity degree in LOMBARDO et al. (2010) } & This trial \\
\hline code & \multicolumn{1}{c}{ description } & $0-4$ scale \\
\hline- & $\begin{array}{l}\text { dead snail } \\
\text { inact- } \\
\text { absence of any perceived movement and body completely withdrawn into shell with shell aperture } \\
\text { closely adhering to the substratum }\end{array}$ & 0 \\
inact+ & $\begin{array}{l}\text { absence of any perceived movement, but body not completely withdrawn into shell; snail } \\
\text { apparently "sleeping", sometimes with production of faeces ("digestion") }\end{array}$ \\
act- & $\begin{array}{l}\text { snail in some perceived movement as "act+" (described below), but at a markedly lower degree of } \\
\text { movement/activity } \\
\text { act+ }\end{array}$ & 2 \\
& $\begin{array}{l}\text { evident movement (roaming; sliding upside down at the water surface; crawling above water level); } \\
\text { active foraging with or without locomotion (radular/tentacle movement); mating; oviposition }\end{array}$ & 4 \\
\hline
\end{tabular}


ness despite the relatively low number of snail and treatment replicates, and the low replication was not expected to artificially depress statistical significance (GOSSELIN 1993). Replication was de facto increased by the twice-daily yet independent observations (LOMBARDO et al. 2010).

Snail activity was analysed with pairwise t-tests, which can be applied to normally or non-normally distributed data (UNDERWOOD 1997). The pairwise t-tests also allowed a repeated-measures approach to the activity data, which were obtained from individuals observed on consecutive days. Pairwise t-tests were used for the two factors separately (observation time and marked vs. unmarked condition) because the relatively small sample sizes may have weakened the power of a three-way (two factors + time) repeated-measures ANOVA.

Snail growth, determined as changes in shell height during the eight-day experiment, was analysed with a type I, two-way ANOVA with experimental condition (marked vs. unmarked snails) and measurement time (initial vs. final) as factors. Since each factor comprised only two levels, a post-hoc test following significant $\mathrm{F}$ values was not needed (e.g., ZAR 2009: 274). Statistical significance for all tests was assumed for $\mathrm{p} \leq 0.05$.

\section{RESULTS}

All the snails exhibited a high degree of daytime and night time activity (Table 2). Although the possible maximum of 40 was never reached, the total activity was within the range of 28-36 and 31-36 for marked and unmarked (control) snails, respectively (Table 2). There was no difference in group activity between marked and unmarked snails (Fig. 4), though marked snails tended to be more active at night (Fig. 5).

All the snails grew during the eight-day experiment (Fig. 6, Table 3). The growth rate (as linear accrual of shell height) was the same for marked and unmarked snails (Fig. 6, Table 3). The daily growth rate (as total shell growth divided by the eight experimental days) ranged from 0.11 to $0.12 \mathrm{~mm} \mathrm{~d}^{-1}$. Marked and unmarked snails produced 30 and 15 egg clutches, respectively, by the end of the experiment.

The white markings persisted without fading or chipping through the eight-day experiment (Fig. 7). However, apparently because of the spiral shell growth, the white markings appeared to move "sideways" around the shells, in some cases becoming barely visible from above (Fig. 7).

Table 2. Activity of marked and unmarked (control) P. acuta individuals during the experiment; $\bigcirc$ - daytime and $\mathbf{O}$ - night time observation. For explanation of numerical values see Table 1. Snails were not followed individually, and are reported from left ("individual 1") to right ("individual 10") according to decreasing observed degree of activity.

\begin{tabular}{|c|c|c|c|c|c|c|c|c|c|c|c|c|c|c|c|c|c|c|c|c|c|c|c|}
\hline \multirow{3}{*}{\multicolumn{2}{|c|}{ Observation }} & \multicolumn{22}{|c|}{ Activity degree of } \\
\hline & & \multicolumn{11}{|c|}{ marked snails (individuals 1 through 10 ) } & \multicolumn{11}{|c|}{ unmarked snails (individuals 1 through 10) } \\
\hline & & 1 & 2 & 3 & 4 & 5 & 6 & 7 & 8 & 9 & 10 & tot & 1 & 2 & 3 & 4 & 5 & 6 & 7 & 8 & 9 & 10 & tot \\
\hline $1 \mathrm{March}$ & O & 4 & 4 & 4 & 4 & 4 & 4 & 3 & 3 & 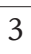 & 2 & 35 & 4 & 4 & 4 & 4 & 3 & 3 & 3 & 3 & 2 & 2 & 32 \\
\hline \multirow[t]{2}{*}{2 March } & 0 & 4 & 4 & 4 & 3 & 3 & 3 & 3 & 3 & 2 & 2 & 31 & 4 & 4 & 4 & 3 & 3 & 3 & 3 & 3 & 3 & 2 & 32 \\
\hline & D & 4 & 4 & 4 & 4 & 4 & 4 & 4 & 3 & 3 & 2 & 36 & 4 & 4 & 4 & 4 & 4 & 4 & 3 & 3 & 2 & 2 & 34 \\
\hline \multirow[t]{2}{*}{3 March } & 0 & 4 & 4 & 4 & 4 & 4 & 4 & 3 & 3 & 3 & 2 & 35 & 4 & 4 & 4 & 4 & 4 & 4 & J & 3 & $J$ & 3 & 36 \\
\hline & O & 4 & 4 & 4 & 4 & 4 & 4 & 4 & 3 & 3 & 2 & 36 & 4 & 4 & 4 & 4 & 4 & 3 & 3 & 2 & 2 & 2 & 32 \\
\hline \multirow[t]{2}{*}{4 March } & 0 & 4 & 4 & 4 & 4 & 4 & 3 & 3 & 3 & J & 2 & 32 & 4 & 4 & 4 & 3 & J & 3 & J & 3 & 2 & 2 & 31 \\
\hline & O & 4 & 4 & 4 & 4 & 4 & 4 & 3 & 3 & 2 & 2 & 3 & 4 & 4 & 4 & 4 & 4 & 4 & 4 & 3 & 2 & 2 & 35 \\
\hline \multirow[t]{2}{*}{5 March } & 0 & 4 & 4 & 4 & 4 & 4 & 3 & 3 & 3 & 2 & 2 & 33 & 4 & 4 & 4 & 4 & 4 & 3 & 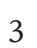 & 3 & 2 & 2 & 33 \\
\hline & 0 & 4 & 4 & 4 & 4 & 4 & 3 & 3 & 2 & 2 & 1 & 31 & 4 & 4 & 4 & 4 & 4 & 3 & 3 & 3 & 3 & 2 & 34 \\
\hline \multirow[t]{2}{*}{6 March } & 0 & 4 & 4 & $T$ & 3 & $J$ & 3 & ? & 2 & & 1 & 2 & 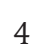 & 4 & $T$ & $J$ & 3 & 3 & 3 & 3 & $J$ & 2 & 32 \\
\hline & $\mathbf{0}$ & 4 & 4 & 4 & 4 & 4 & 4 & J & 3 & 2 & 2 & 3 & 4 & 4 & 4 & 4 & 4 & 3 & 3 & 3 & 2 & 2 & 33 \\
\hline \multirow[t]{2}{*}{7 March } & 0 & 4 & 4 & 4 & 4 & 3 & 3 & 3 & 3 & 2 & 2 & 32 & 4 & 4 & 4 & 4 & 4 & 3 & 3 & 3 & 3 & 2 & 34 \\
\hline & O & 4 & 4 & 4 & 4 & 4 & 3 & 3 & 3 & 3 & 2 & 34 & 4 & 4 & 4 & 4 & 3 & 3 & 3 & 2 & 2 & 2 & 31 \\
\hline \multirow[t]{2}{*}{8 March } & 0 & 4 & 4 & 4 & 4 & 4 & 3 & 2 & 3 & 2 & 3 & 35 & 4 & 4 & 4 & 4 & 1 & 4 & $J$ & 3 & 3 & 2 & 35 \\
\hline & O & 4 & 4 & 4 & 4 & 4 & 4 & 3 & 3 & 3 & 2 & 35 & 4 & 4 & 4 & 4 & 3 & 3 & 3 & 2 & 2 & 2 & 31 \\
\hline 9 March & 0 & 4 & 4 & 4 & 4 & 4 & 3 & $J$ & 2 & 2 & 2 & 32 & 4 & 4 & 4 & 4 & 3 & 3 & 3 & 3 & 3 & 3 & 34 \\
\hline
\end{tabular}



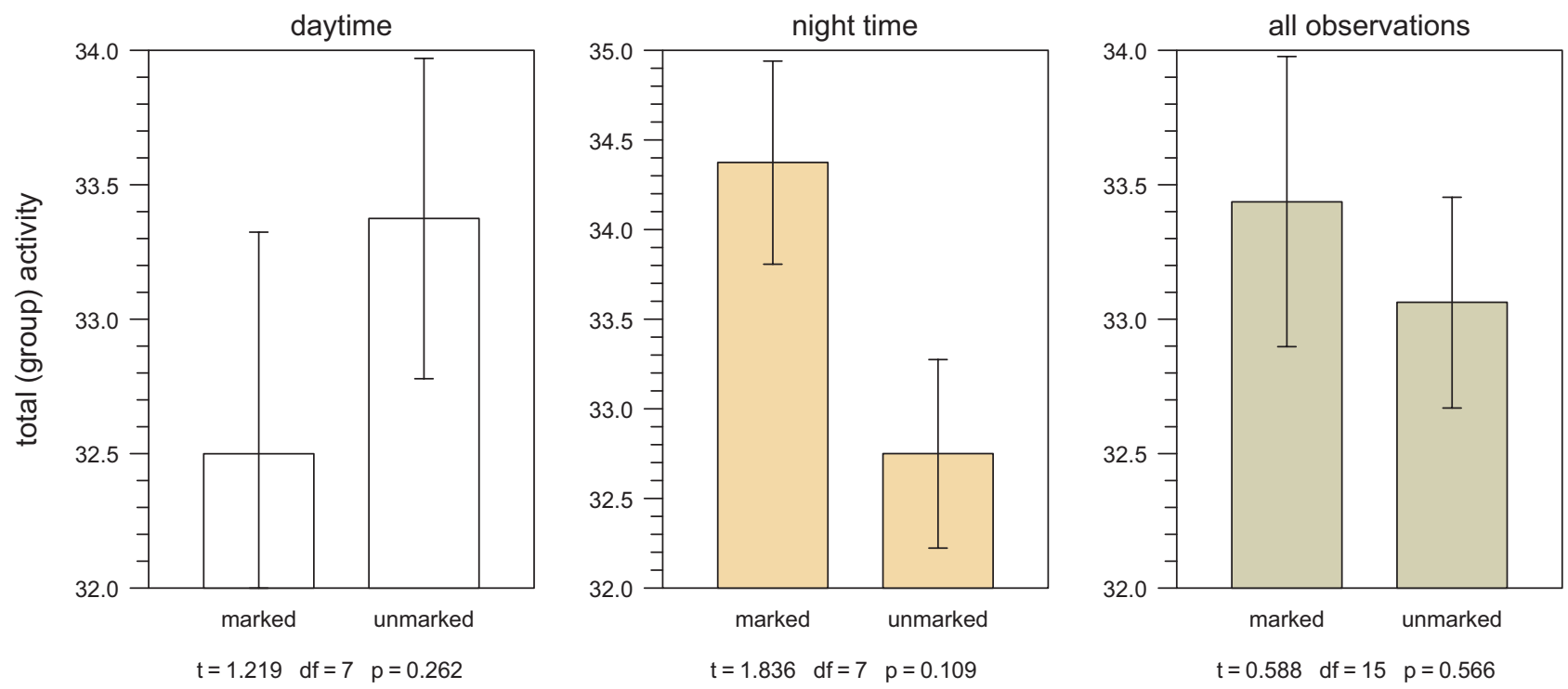

Fig. 4. Average total activities of marked and unmarked individuals in daytime, night time, and as experiment-wide total; mean \pm standard error. Pairwise t-tests are included; $\mathrm{n}_{\text {marked }}=\mathrm{n}_{\text {unmarked }}=\mathrm{df}+1$

\section{DISCUSSION}

The marking did not influence the snail activity appreciably, with the sole possible exception of a sub-significant $(\mathrm{p}=0.08)$ higher activity of marked snails at night (Figs 4, 5). As oviposition in freshwater gastropods often occurs at night (e.g., VAN DER STEEN 1967, but see TER MAAT et al. 2012), the higher activity of marked snails at night could be related to the higher oviposition, but this hypothesis remains untested for this experiment or for P. acuta. Also, P. acuta is a particularly active species (e.g., PERRIN 1986, LOMBARDO et al. 2010), with small differences in activity in daylight or at night (LOMBARDO et al. 2010), and the mildly higher activity of marked snails at night (Fig. 5) may have been due to casual factors, possibly including sustained interactions among snails searching for mates. [LOMBARDO et al. (2010) tested individual snails observed in isolation.] Although the range and mean values for initial body size were similar for marked and unmarked snails (Fig. 6), the group of marked snails may have comprised more sexually active individuals in "female mode", following the pre-trial random division of the experimental snails, thus leading to a higher number of egg clutches produced by marked snails at the end of the experiment. However, the reason behind the higher number of egg clutches produced by marked snails remains unexplained, and other experiments with higher replication may be needed to address this issue.

The absence of marking effects on snail activity in our experiment with $P$. acuta is compatible with earlier findings of absence of marking effects on snail activity, locomotion, horizontal dispersion, anti-predator behaviour, reproductive behaviour, susceptibili- ty to parasite infection, and survival for $P$. acuta and other aquatic gastropod species (FENWICK \& AMIN 1983, O'KeEFFE 1985, GOATER et al. 1989, BURRIS et al. 1990, MCRAE \& LEPITZKI 1994, HENRY \& JARNE 2007, HÄDERER et al. 2009, COUTELleC \& CAQUET 2011, MORTON \& SiLlimAn 2020, TARIEL et al. 2020).

The marking also did not have any influence on the snail growth (Fig. 6, Table 3), supporting earlier findings for terrestrial gastropods (BAKER 1988, BAMINGER 2000), aquatic gastropods in general
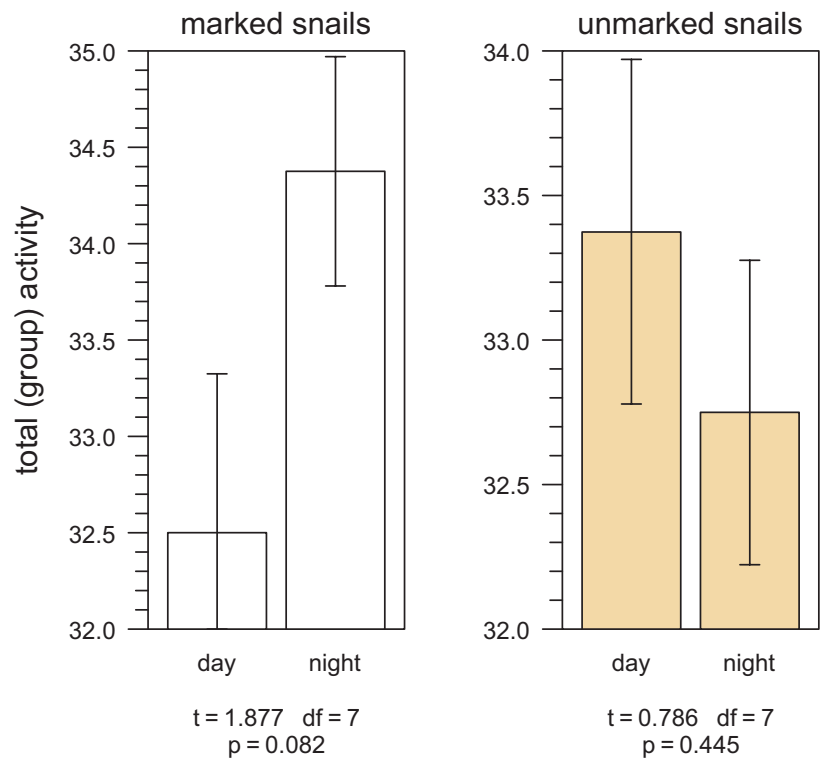

Fig. 5. Total activities of individually marked and unmarked $P$. acuta in daytime vs. night time; mean \pm standard error. Pairwise t-tests are included; $\mathrm{n}_{\text {marked }}=\mathrm{n}_{\text {unmarked }}=\mathrm{df}+1$ 
(FENWICK \& AMIN 1983, GOSSElin 1993, MCRAE \& LEPITZKI 1994), and P. acuta in particular (HENRY \& JARNE 2007). Individual growth rates are difficult to compare across the literature because of the variety of experimental or rearing conditions (DILLON 2000: 176-177). The daily individual growth for our experimental $P$. acuta was within the range of $\sim 0.11-$ $0.12 \mathrm{~mm} \mathrm{~d}^{-1}$ as shell height accrual, which is twice as much as that reported for P. acuta (PERRIN 1986, HENRY \& JARNE 2007) or for the closely related $P$. fontinalis (DE WIT 1955). However, all such studies report mean growth rates from medium- to long-term observations, and physids and other aquatic gastropods tend to grow much faster when they are young (before reproductive age: DE WIT 1955, PERRIN 1986), possibly as an adaptation to reach a refuge size against potential predators (e.g., CROWL \& $\mathrm{COVICH}$ 1990, AULD \& RELYEA 2008). GOSSELIN (1993) also reported much faster individual growth for juveniles than adults of the relatively slow growing marine gastropod Nucella (=Thais) emarginata (Deshayes, 1839). The relatively fast daily growth rate observed for our

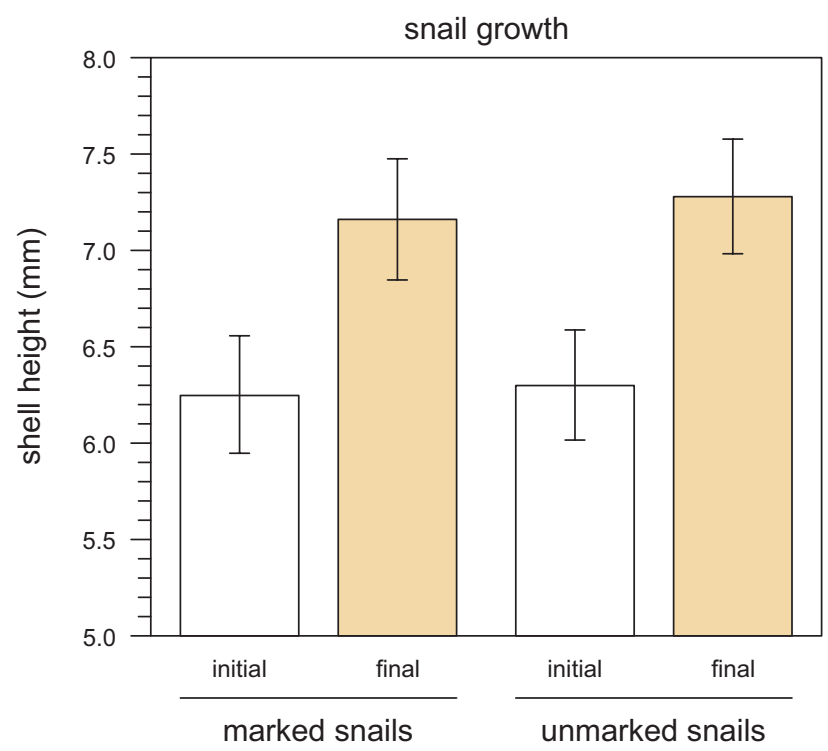

Fig. 6. Snail size as shell height $(\mathrm{mm})$ at the beginning and end of the eight-day experiment; mean \pm standard error, $\mathrm{n}=10$ for each group. For statistical analysis see Table 3

pre-reproductive age $P$. acuta therefore seems to align with the scant data from the literature.

The marking with the Sipa 150 car-body, oil-based paint did not fade during the eight-day experiment (Fig. 7), and persisted for at least six weeks after the end of the experiment. While we stopped our post-experiment qualitative observations after $\sim$ six weeks, snail marking with car-body paint, enamel, or fingernail varnish was observed to persist for $\sim$ two to six months in the laboratory (GOSSELIN 1993, HENRY \& JARNE 2007) and in the field (GOATER et al. 1989, BURRIS et al. 1990, GOSSELIN 1993), though markings in the field tended to last slightly less (GOSSELIN 1993). Although the marking persisted without chipping or fading for the experimental eight days (Fig. 7) and for at least another six-seven weeks, the marked dots tended to "disappear" under the growing shell spires for our fast-growing pre/peri-reproductive $P$. acuta. GOSSELIN (1993), who followed individual snails from hatchlings ( $\sim 1-2 \mathrm{~mm}$ of shell height) to adult size ( $\sim 28 \mathrm{~mm}$ of shell height attained after one year of observations), had to re-paint his experimental snails 71 days into his experiment; once growth slowed down, the marking did not need to be reiterated.

Our results support earlier findings that oil-based, waterproof car-body paint is a reliable and suitable method to distinguish individual freshwater $P$. acu$t a$ at least in the short and medium term. The suitability of car-body paint may be similar to that of fingernail varnish [used among others by GOSSELIN (1993) and MCRAE \& LEPITZKI (1994)] and plastic tags glued to snail shells (HENRY \& JARNE 2007). However, plastic tags cannot be applied to small-bodied snails, while car-body paint or fingernail varnish can be applied to snails as small as $3 \mathrm{~mm}$ in shell

Table 3. Result of the two-way ANOVA testing for differences in shell height in Fig. 6. Treatment $=$ marked vs. unmarked snails; time $=$ initial vs. final shell height

\begin{tabular}{lccccc}
\hline & SS & df & MS & F & p \\
\hline treatment & 0.072 & 1 & 0.072 & 0.079 & 0.779 \\
time & 8.930 & 1 & 8.930 & 9.854 & 0.003 \\
interaction & 0.012 & 1 & 0.012 & 0.013 & 0.908 \\
error & 32.625 & 36 & 0.906 & - & - \\
total & 41.640 & 39 & - & - & - \\
\hline
\end{tabular}
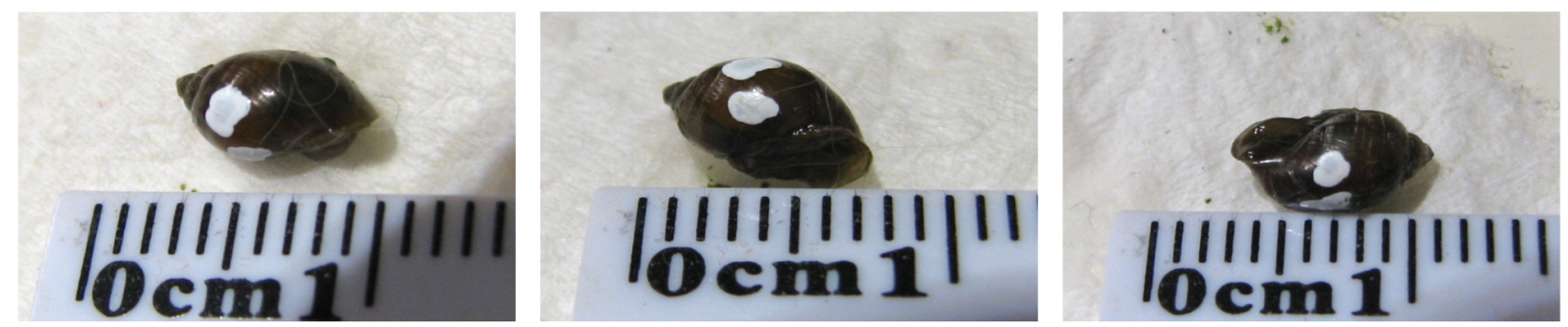

Fig. 7. Representative marked snails at the end of the experiment, showing the apparent sideways "movement" of the white marking dots as snails grew 
Table 4. Maximum number of snails that can be simultaneously identified as separate individuals with all possible combinations of two marker dots of different colours. The number of possible colour combinations (and hence of individually distinguishable snails) regardless of dot order is $n^{k}-\frac{n}{2} \times(n-1)$, where $n=$ number of marker colours and $\mathrm{k}=$ number of dots $(\mathrm{k}=2$ in our case) (first Table column); the maximum number of colour combinations that includes also the combinations in different order (second Table column) is $\mathrm{n}^{\mathrm{k}}$. A graphical example is given for the first Table row when only two marker colours are available to paint two identifying dots $(\mathrm{k}=2)$

\begin{tabular}{ccc}
\hline \multirow{2}{*}{$\begin{array}{c}\text { Number } \\
\text { of marker } \\
\text { colours }\end{array}$} & $\begin{array}{c}\text { Number of identifiable snail individuals } \\
\text { number of colour } \\
\text { combinations } \\
\text { regardless of dot order } \\
{\left[\mathrm{n}^{\mathrm{k}}-\frac{\mathrm{n}}{2} \times(\mathrm{n}-1)\right]}\end{array}$ & $\begin{array}{c}\text { number of colour } \\
\text { combinations } \\
\text { considering dot order } \\
\left(\mathrm{n}^{\mathrm{k}}\right)\end{array}$ \\
\hline 2 & 3 & 4 \\
& $\bullet \bullet$ & $\bullet \bullet$ \\
& $\circ \circ$ & $\circ$ \\
& $\bullet$ or $\circ$ & $\bullet$ \\
3 & & 9 \\
4 & 6 & 16 \\
5 & 10 & 25 \\
6 & 15 & 36 \\
7 & 21 & 49 \\
8 & 28 & 64 \\
9 & 36 & 81 \\
10 & 45 & 100 \\
\hline
\end{tabular}

height (HENRY \& JARNE 2007), or even to smaller snails, using a trimmed brush with only 3-5 strands (GOSSELIN 1993). Among the most effective marking methods tested by HENRY \& JARNE (2007), car-body paint also has the smallest possible influence on the snails, as two 2 -mm dots on $\sim 4-7$-mm-long P. acuta weigh $<0.05 \%$ of the marked individual (HENRY \& JARNE 2007). Car-body paint has the additional advantage that it can be applied within 3-4 min of out-of-the-water pre-experiment handling, thus with minimal stress for the snails (GOSSELIN 1993, HENRY \& JARNE 2007), though the marking may need to be repeated for medium- to long-term observations (Fig. 7; Gosselin 1993). Car-body paint or nail varnish can be applied to a variety of relatively small-bodied snail species such as physids (this study, DE WIT 1955, HENRY \& JARNE 2007, TARIEL et al. 2020) and bithyniids (MCRAE \& LEPITZKI 1994), and are potentially applicable to laboratory (e.g., HENRY \& JARNE 2007, TARIEL et al. 2020) and field experiments (e.g., BURRIS et al. 1990, GOSSELIN 1993).

To summarise, the results suggest that the twodot marking of experimental snails can be adopted for detailed experiments with no risk of influencing or confounding the results, at least using this particular brand and type of marker (Figs 1-3). Although the manufacturer did not provide information on the components of the paint in their SP150 marker, such markers are advertised as car-body paint and described as non-toxic and CE- and RoHS compliant. Our experimental approach could be easily adapted to test other marker types, as other investigators see fit.

The use of two dots allows several snails in a single experimental aquarium to be distinguished individually. It is impossible to write numbers or draw symbols on the shells of small-bodied snails such as P. acu$\mathrm{ta}$, but two $\sim 2$-mm dots produced with a fine-point marker are clearly visible from above (Figs 1-3). The use of colour markers thus would make it possible to distinguish several experimental snails by combinations of marking colours (Table 4). HENRY \& JARNE (2007) found no effect of car-body colour on life history traits of $P$. acuta, in contrast to other less reliable methods such as gouache paint. Combinations of one to three colour-coded dots can uniquely mark a higher number of snails simultaneously (GOSSELIN 1993).

The water in the experimental containers (both for the marked and unmarked snail groups) appeared foul after the first four daily cycles of observations. Although the fouling did not seem to have appreciable effects on snail growth, oviposition, or behaviour, cycles of observations in small experimental containers should be carried out at regular intervals to avoid possible confounding effects of fouling water.

\section{ACKNOWLEDGEMENTS}

This research has been self-produced with no external financial support. All co-authors have read and approved the final manuscript version. Mr. MASSIMO EVANGELISTA's kindness and help during field collection is greatly appreciated. We also thank Prof. ANDRZEJ LESICKI and three anonymous reviewers for their critical comments that improved and enriched the original manuscript.

\section{REFERENCES}

ANDERSON R. 2003. Physella (Costatella) acuta Draparnaud in Britain and Ireland, its taxonomy, origins and relationship to other introduced Physidae. Journal of Conchology 38: 7-21.
AULD J. R., RELYEA R. A. 2008. Are there interactive effects of mate availability and predation risk on life history and defence in a simultaneous hermaphrodite? Journal of Evolutionary Biology 21: 1371-1378. https://doi.org/10.1111/j.1420-9101.2008.01562.x 
BAKER G. H. 1988. Dispersal of Theba pisana (Mollusca: Helicidae). Journal of Applied Ecology 25: 889-900. https://doi.org/10.2307/2403753

BAMINGER H. 2000. Effects of passive transponder used for individual marking on mating propensity in Arianta arbustorum (Helicidae, Gastropoda). Arianta 3: 39-46.

BURKS R. L., LODGE D. M., JEPPESEN E., LAURIDSEN T. L. 2002. Diel horizontal migration of zooplankton: costs and benefits of inhabiting the littoral. Freshwater Biology 47: 343-365. https://doi.org/10.1046/j.1365-2427.2002.00824.x

BURRIS J. A., BAMFORD M. S., STEWART A. J. 1990. Behavioral responses of marked snails as indicators of water quality. Environmental Toxicology and Chemistry 9: 69-76. https://doi.org/10.1002/etc.5620090109

CATTANEO A., KALFF J. 1986. The effect of grazer size manipulation on periphyton communities. Oecologia 69: 612-617. https://doi.org/10.1007/BF00410371

CHAUdRY M., Morgan E. 1987. Factors affecting the growth and fecundity of Bulinus tropicus (Krauss) (Gastropoda). Journal of Molluscan Studies 53: 52-61. https://doi.org/10.1093/mollus/53.1.52

CiANFANELli S., LORI E., BODON M. 2007. Non-indigenous freshwater molluscs and their distribution in Italy. In: GHERARDI F. (ed.). Biological invaders in inland waters: Profiles, distribution and threats. Springer, Dordrecht, NL, pp. 103-121. https://doi.org/10.1007/978-1-4020-6029-8 5

Coutellec M.-A., Caquet T. 2011. Heterosis and inbreeding depression in bottlenecked populations: a test in the hermaphroditic freshwater snail Lymnaea stagnalis. Journal of Evolutionary Biology 24: 2248-2257. https://doi.org/10.1111/j.1420-9101.2011.02355.x

Crowl T. A., Covich A. P. 1990. Predator-induced life history shifts in a freshwater snail. Science 247: 949-951. https://doi.org/10.1126/science.247.4945.949

DE WIT W. F. 1955. The life cycle and some other biological details of the fresh-water snail Physa fontinalis (L.). Basteria 19: 35-73.

DILLON R. T. JR. 2000. The ecology of freshwater molluscs. Cambridge University Press, Cambridge, UK. https://doi.org/10.1017/CBO9780511542008

Dillon R. T. JR., Wethington A. R., Rhett J. M., SMith T. P. 2002. Populations of the European freshwater pulmonate Physa acuta are not reproductively isolated from American Physa heterostropha or Physa integra. Invertebrate Biology 121: 226-234. https://doi.org/10.1111/j.1744-7410.2002.tb00062.x

DOYLE R. D., SMART R. M. 1998. Competitive reduction of noxious Lyngbya wollei mats by rooted aquatic plants. Aquatic Botany 61: 17-32. https://doi.org/10.1016/S0304-3770(98)00060-6

Elger A., LEMOINE D. 2005. Determinants of macrophyte palatability to the pond snail Lymnaea stagnalis. Freshwater Biology 50: 86-95. https://doi.org/10.1111/j.1365-2427.2004.01308.x

EVANGELISTA M., VALLINOTTO E. 2009. Indagine preliminare sugli invertebrati nel Sito di Importanza Comunitaria
IT1110035 "Stagni di Poirino-Favari," Relazione Tecnica preparata per l'Associazione onlus Natura Cascina Bellezza, con la collaborazione del World Wildlife Fund.

FENWICK B., AMIN M. A. 1983. Marking snails with nail varnish as a field experimental technique. Annals of Tropical Medicine and Parasitology 77: 387-390. https://doi.org/10.1080/00034983.1983.11811726

Frodge J. D., Thomas G. L., PAuley G. B. 1990. Effects of canopy formation by floating and submergent aquatic macrophytes on the water quality of two shallow Pacific Northwest lakes. Aquatic Botany 38: 231-248. https://doi.org/10.1016/0304-3770(90)90008-9

GÉRARD C. 2001. Structure and temporal variation of trematode and gastropod communities in a freshwater ecosystem. Parasite 8: 275-287. https://doi.org/10.1051/parasite/2001084275

Goater T. M., Shostak A. W., Williams J. A., EsCH G. W. 1989. A mark-recapture study of trematode parasitism in overwintered Helisoma anceps (Pulmonata), with special reference to Halipegus occidualis (Hemiuridae). Journal of Parasitology 75: 553-560. https://doi.org/10.2307/3282905

Gosselin L. A. 1993. A method for marking small juvenile gastropods. Journal of the Marine Biological Association of the United Kingdom 73: 963-966. https://doi.org/10.1017/S0025315400034834

Gross E. M., LOMBARDO P. 2018. Limited effect of gizzard sand on consumption of the macrophyte Myriophyllum spicatum by the great pond snail Lymnaea stagnalis. Hydrobiologia 812: 131-145. https://doi.org/10.1007/s10750-016-2890-8

HÄDERER I. K., WeRminghaUSEN J., MichiEls N. K., TIMMERMEYER N., ANTHES N. 2009. No effect of mate novelty on sexual motivation in the freshwater snail Biomphalaria glabrata. Frontiers in Zoology 6: 23. https://doi.org/10.1186/1742-9994-6-23

Heidinger I. M. M., Poethke H.-J., Bonte D., Hein S. 2009. The effect of translocation on movement behaviour-A test of the assumptions of behavioural studies. Behavioural Processes 82: 12-17. https://doi.org/10.1016/j.beproc.2009.03.001

HENRY P.-Y., JARNE P. 2007. Marking hard-shelled gastropods: tag loss, impact on life history traits, and perspectives in biology. Invertebrate Biology 126: 138-153. https://doi.org/10.1111/j.1744-7410.2007.00084.x

JASSER I. 1995. The influence of macrophytes on a phytoplankton community in experimental conditions. Hydrobiologia 306: 21-32. https://doi.org/10.1007/BF00007855

JONES J. I., EATON J. W., HARDWICK K. 2000. The influence of periphyton on boundary layer conditions: a $\mathrm{pH}$ microelectrode investigation. Aquatic Botany 67: 191-206. https://doi.org/10.1016/S0304-3770(00)00089-9

JONES J. I., YOUNG J. O., HAYNES G. M., MOSS B., EATON J. W., HARDWICK K. J. 1999. Do submerged aquatic plants influence their periphyton to enhance the growth and reproduction of invertebrate mutualists? Oecologia 120: $463-474$.

https://doi.org/10.1007/s004420050879 
KÖRNER S., NiCKLISCH A. 2002. Allelopathic growth inhibition of selected phytoplankton species by submerged macrophytes. Journal of Phycology 38: 862-871. https://doi.org/10.1046/j.1529-8817.2002.t01-102001.x

LOMBARDO P. 2001. Effects of freshwater gastropods on epiphyton, macrophytes, and water transparency under meso- to eutrophic conditions. PhD Dissertation. Kent State University, Kent, OH.

Lombardo P., Miccoli F. P., GiUstini M., Cicolani B. 2010. Diel activity cycles of freshwater gastropods under natural light: patterns and ecological implications. Annales de Limnologie - International Journal of Limnologie 46: 29-40.

https://doi.org/10.1051/limn/2010004

Includes Supplementary Material and an Erratum/ Addendum [Ann. Limn. 47 (2011): 395-396]. https://doi.org/10.1051/limn/2011049

LOMBARdo P., MJELDE M., KÄLlQVIST T., BRETTUM P. 2013. Seasonal and scale-dependent variability in nutrientand allelopathy-mediated macrophyte-phytoplankton interactions. Knowledge and Management of Aquatic Ecosystems 409: 10. https://doi.org/10.1051/kmae/2013055

LOWE R. L., HUNTER R. D. 1988. Effect of grazing by Physa integra on periphyton community structure. Journal of the North American Benthological Society 7: 29-36. https://doi.org/10.2307/1467828

Lydeard C., Campbell D., Golz M. 2016. Physa acuta Draparnaud, 1805 should be treated as a native of North America, not Europe. Malacologia 59: 347-350. https://doi.org/10.4002/040.059.0213

McCollum E. W., Crowder L. B., MCCOllum S. A. 1998. Complex interactions of fish, snails, and littoral zone periphyton. Ecology 79: 1980-1994. https://doi.org/10.1890/0012-9658(1998)079[1980 :CIOFSA]2.0.CO;2

MCRAE M., LEPITZKI D. A. W. 1994. Population estimation of the snail Bithynia tentaculata (Gastropoda: Prosobranchia) using mark-recapture and the examination of snail movement in pools. Canadian Field Naturalist 108: 58-66.

MichALIK-KUCHARZ A. 2008. The occurrence and distribution of freshwater snails in a heavily industrialised region of Poland (Upper Silesia). Limnologica 38: 4355.

https://doi.org/10.1016/j.limno.2007.09.003

MORTON J. P., Silliman B. R. 2020. Parasites enhance resistance to drought in a coastal ecosystem. Ecology 101(1): e02897. https://doi.org/10.1002/ecy.2897

NEWMAn R. M. 1991. Herbivory and detritivory on freshwater macrophytes by invertebrates: a review. Journal of the North American Benthological Society 10: 89114. https://doi.org/10.2307/1467571

O'KeEFFE J. H. 1985. Population biology of the freshwater snail Bulinus globosus on the Kenya coast. 1. Population fluctuations in relation to climate. Journal of Applied Ecology 22: 73-84.

https://doi.org/10.2307/2403328

PeCKARSKY B. L., CowAn C. A. 1995. Microhabitat and activity periodicity of predatory stoneflies and their mayfly prey in a western Colorado stream. Oikos 74: 513-521. https://doi.org/10.2307/3545997

PĘCZUŁA W., MiECZAN T., TARKOWSKA-KUKURYK M. 2017. Distribution of planktonic crustaceans and its diurnal changes in a hypertrophic shallow lake: does the switch from turbid-water state to clear-water state matters? Annales de Limnologie - International Journal of Limnology 53: 369-376. https://doi.org/10.1051/limn/2017021

PERRIN N. 1986. Les paramètres du cycle vital de Physa acuta (Gastropoda, Mollusca) en milieu expérimental. Revue Suisse de Zoologie 93: 725-736. https://doi.org/10.5962/bhl.part.79508

PIECZYŃSKA E. 2003. Effect of damage by the snail Lymnaea (Lymnaea) stagnalis (L.) on the growth of Elodea canadensis Michx. Aquatic Botany 75: 137-145. https://doi.org/10.1016/S0304-3770(02)00170-5

RID S. 2008. Herbivorie von Lymnaea stagnalis an Wasserpflanzen. Staatsexamensarbeit (report/thesis for final scientific internship as secondary school teacher). University of Konstanz, Konstanz, Germany.

SOsZKA G. J. 1975. Ecological relations between invertebrates and submerged macrophytes in the lake littoral. Ekologia Polska 23: 393-415.

SPyrA A., CiePlOK A., STRZElEC M., BABCZYŃSKA A. 2019. Freshwater alien species Physella acuta (Draparnaud, 1805) - A possible model for bioaccumulation of heavy metals. Ecotoxicology and Environmental Safety 185: 109703.

https://doi.org/10.1016/j.ecoenv.2019.109703

TARIEl J., LuQUeT É., PlÉNET S. 2020. Interactions between maternal, paternal, developmental, and immediate environmental effects on anti-predator behavior of the snail Physa acuta. Frontiers in Ecology and Evolution 08: 591074. https://doi.org/10.3389/fevo.2020.591074

Ter MaAt A., Pieneman A. W., Koene J. M. 2012. The effect of light on induced egg laying in the simultaneous hermaphrodite Lymnaea stagnalis. Journal of Molluscan Studies 78: 262-267.

https://doi.org/10.1093/mollus/eys008

Toledo R., Muñoz-Antoli C., PÉrez M., Esteban J. G. 1998. Larval trematode infections in freshwater gastropods from the Albufera Natural Park in Spain. Journal of Helminthology 72: 79-82. https://doi.org/10.1017/S0022149X00001024

TóTH V. R. 2013. The effect of periphyton on the light environment and production of Potamogeton perfoliatus L. in the mesotrophic basin of Lake Balaton. Aquatic Sciences 75: 523-534. https://doi.org/10.1007/s00027-013-0297-4 
UNDERWOOD A. J. 1997. Experiments in ecology: their logical design and interpretation using analysis of variance. Cambridge University Press, Cambridge, UK. https://doi.org/10.1017/CBO9780511806407

VAN DER STEEN W. J. 1967. The influence of environmental factors on the oviposition of Lymnaea stagnalis (L.) under laboratory conditions. Archives Néerlandaises de Zoologie 17: 403-468.

https://doi.org/10.1163/036551667X00083

VERMAAT J. E., SANTAMARÍA L., RoOs P. J. 2000. Water flow across and sediment trapping in submerged macrophyte beds of contrasting growth form. Archiv für Hydrobiologie 148: 549-562.

https://doi.org/10.1127/archiv-hydrobiol/148/2000/549

VINARSKI M. 2017. The history of an invasion: phases of the explosive spread of the physid snail Physella acuta through Europe, Transcaucasia and Central Asia. Biological Invasions 19: 1299-1314.

https://doi.org/10.1007/s10530-016-1339-3
Wethington A. R., LydEARD C. 2007. A molecular phylogeny of Physidae (Gastropoda: Basommatophora) based on mitochondrial DNA sequences. Journal of Molluscan Studies 73: 241-257.

https://doi.org/10.1093/mollus/eym021

ZAR J. H. 2009. Biostatistical analysis, 5th ed. Prentice Hall / Pearson, Upper Saddle Creek, NJ.

Zhang P., van Leeuwen C. H. A., Bogers D., Poelma M., XU J., BAKKER E. S. 2020. Ectothermic omnivores increase herbivory in response to rising temperature. Oikos 129: 1028-1039. https://doi.org/10.1111/oik.07082

Received: February 10th, 2021

Revised: April 28th, 2021

Accepted: May 6th, 2021

Published on-line: May 25th, 2021 